\title{
The Interplay of Textual and
} Interactional Resources in Collective Literacy Practices in Nordic Classrooms: Editorial Introduction

There is societal consensus in democratic countries all over the world on how important it is for young people to acquire literacy skills and competences in order to be able to participate in the labor market and as citizens when they reach adulthood. This consensus is expressed, for instance, in policy documents such as national curricula and syllabi as well as in various educational programs aimed at enhancing teacher competence and enhancing all students' literacy. With this special issue, we argue that it is important that educational literacy research explores different aspects of participation in collective literacy activities in classrooms to promote understanding of the complexity of conditions under which students become democratic participants in contemporary society. The next five articles contribute to this enterprise by describing and discussing how literacy practices in contemporary Nordic education are shaped in situated interactions in contexts that are socially and materially constituted.

From a democratic perspective, access to reading and writing is about "making sense of the world, about building, critiquing, and imagining possible worlds, possible futures, and possible lives" (Luke, 2012, p. 8). General education offered by schools is perhaps the societal institution with the most potential to provide a democratic meeting space in which all citizens receive fair and equal access to literacy and education. However, in recent decades these societal aspirations for democracy and citizenship have been engulfed by a global discourse of competition between educational systems on a national level, stressing the need for accountability through testing in order to ensure the realization of educational goals (cf. Ball, 2012; Breakspear, 2012; Hamilton, 2012; Hursh, 2007; Lingard \& Rawolle, 2011; Grek, 2009). Education and test results have become important currencies in global economic competition. International rankings promoted by economic organizations, such as the Organization for Economic Co-operation and Development (OECD), 


\section{Hermansson et al.}

have had tremendous impact on educational practice and policy, not least in relation to literacy. In the OECD's Definition and Selection of Competences (DeSeCo), literacy is described as an essential tool for "functioning well in society and the workplace and participating in an effective dialogue with others" (OECD, 2005). The aim with $\mathrm{DeSeCo}$ is to provide a framework that could guide longer-term assessments such as PISA, a test that measures and compares literacy results between nations and over time. Tests like PISA, TIMMS and PIRLS have had huge impact on media and political debates and can be seen as examples of how neoliberal discourse in these areas contributes to shaping a new global knowledge economy (Lauder, Brown, Dillabogh and Halsey, 2006). In sum, we can state that the contextual framing of literacy education has changed due to the development of a neoliberal agenda within education, promoting efficiency, marketization, accountability and comparisons of outcomes on different levels. A consequence of these neoliberal educational policies is an increasing emphasis on individualization in schools, both due to reforms allowing for individual school selection, which renders education an individual life project, and in relation to an increasing focus on student outcomes.

The view of education as a private and individual project has also been promoted from other ideological stances, not least in the Nordic countries, where there has long been a tradition of progressive educational discourse that includes ideas about placing "the child in the centre" and "the active child" (Carlgren et al, 2006). Originally, these ideas challenged traditional patterns of frontal teaching in the classroom by drawing on constructivist theories of learning and pedagogies that promoted individual instruction that could meet individual students' own interests and experiences. As a result, teaching patterns in Nordic countries changed and became more focused on individual work, with a strong focus on students' ability to take responsibility for themselves and their own learning (cf. Vinterek, 2006). These two driving forces - progressive pedagogies and neoliberal politics - are in many ways opposed. Together they have led to changes in the organization of schooling at all levels; from being a public and societal enterprise, education has become a more private and individualistic project (Englund, 1993).

In this discourse, the individual and his/her accomplishments and results are foregrounded while how individuals work together and cooperate is relegated to the background. As a consequence, literacy is often defined in terms of individual students' development in relation to decoding and reading comprehension skills. However, this emphasis on students' individual literacy acquisition in many ways contradicts the research findings of the past three decades that have established that literacy is fundamentally social (Brice Heath 1983; Street 2005; Barton 1994; Haas Dyson 1997; among others). Primarily drawing on sociocultural understandings of literacy and learning, this research emphasizes communicative and social uses of literacy against a backdrop of a diverse media landscape. These social aspects are particularly salient in schools which are typically feature learning situations in socially diverse and rich environments. This special issue adopts a literacy 
perspective according to which students are acknowledged to participate in a wide range of school-bound literacy practices for different purposes and in different school subjects. These literacy practices take shape in situated interactions around different texts and in relation to the contextual framing of teaching instruction, in which seemingly individual work is also shown to be socially framed and to be related to the social and collective environment of the classroom (c.f. Tanner, 2014).

The increasing individualization in education leads to fundamental contextual changes that influence teachers' and students' everyday classroom interactions. Other contemporary changes of significance for teaching and learning concern the digitization of society at large, resulting in new media technologies that compete with traditional paper-based technologies in classroom activities. These contextual changes do not only take place on a discursive level, but also alter the conditions for teaching and learning in the social and material setting of classrooms. We therefore deem it urgent that educational research should enter classrooms and adopt the perspective of classroom participants (teachers and students) to try to understand how these different contextual changes affect everyday literacy practices.

The collection of articles in this special issue developed out of fruitful collaboration between Nordic literacy researchers at two conference symposia: "The interplay of textual and interactional resources in collective reading and writing practices in Nordic classrooms" that was held as part of ECER 2015 in Budapest, and "Interplay with texts through different media" which formed part of NERA 2016 in Helsinki. These symposia brought together studies that sought to explore teaching and learning in collective classroom literacy practices from different methodological angles, and the initiative for this special issue came from the discussions at these symposia.

Although the five articles that resulted in this collaboration make use of diverse theoretical and methodological approaches, they are all anchored in a social understanding of literacy and share an interest in high-lighting the social and collective nature of literacy. A common point of departure for the articles in this special issue is an interest in the social and collective nature of literacy learning in classrooms. Educational literacy research urgently needs to address this to provide substantial empirical contributions to contemporary edupolitical debates about issues associated with the standard and content of literacy education in Nordic schools.

In her article, "Disembodied Voice and Embodied Affect: e-Reading in Early Childhood Education", Carina Hermansson explores what happens in the digital classroom when six-year-olds read a fictional electronic book. She examines children's engagement with e-books using an affective methodology influenced by Deleuze which provides a way of attending to the highly dynamic encounters between bodies, ideas and materiality. In the analysis it becomes evident that the digital voice is a vital component for activating engagement in and a drive for reading through the moments and movements of embodied reading.

In the second article, "Children's Democratic Experiences in a Collective Writing Process: Analyzing Classroom Interaction in Terms of Deliberation", Eva Hultin 


\section{Hermansson et al.}

investigates the interactional conditions constituted in a collective writing process involving six nine-year-old children and their teacher. The study takes an ethnographical approach and the interaction is analyzed in terms of deliberativedemocratic qualities. Furthermore, the aim of the analysis is twofold: in addition to analyzing the interactional conditions, the set of deliberative criteria operationalized in the analysis tested for its usefulness as an analytic tool for classroom interaction.

The third article, "Classroom Interaction and Its Potential for Literacy Learning", by Catarina Schmidt and Marianne Skoog, discusses interactional conditions and possibilities for literacy learning across the curriculum in the middle school years. The analysis investigates different registers of repertoires for interaction through organization of teaching and learning talk. The authors pay special attention to the question of how students can be efficiently scaffolded in their literacy development and points to the important role played by interaction in students' literacy development through subject content and vice versa. The article argues for the necessity of considering the students participants with resources, and for increasing their possibilities of actively taking part in the initial, intermediate and lasting phases of different subject areas.

In "Interactional Organization and Pedagogic Aims of Reading Aloud Practices in L1 Education in the Sixth Grade", Anna Slotte and Liisa Tainio examine the activity of reading aloud in L1-classrooms. This activity frequently occurs in primary education but is also widely used in the upper grades. Using conversation analysis as their methodological approach, they investigate video-recorded classroom interaction in Finnish comprehensive schools. Their analysis encompasses reading aloud exercises with reference to genre, text sources and recipients' visual access/nonaccess to the text. The analysis shows how the reading of a text creates a shared reference point in the classroom, through which the content and ideology of the text is emphasized and deeper knowledge about the text is facilitated. Based on their results, the authors further discuss the potential of read-alouds as pedagogical tools for developing skills in a classroom setting.

In the fifth contribution, "Material Texts as Objects in Interaction - Constraints and Possibilities for Dialogicity in Reading Instruction", Marie Tanner, Christina Olin-Scheller, and Michael Tengberg explore the role that texts have not only as bearers of content information, but also as material objects involved in the interaction between teachers and students. In this article, the methodological approach is also conversation analysis and the analysis shows how texts as material objects are used in ways that challenge the teacher's dialogical intentions in reading instruction. This leads to critical aspects of reading becoming subordinated to the aim of problem solving. The article discusses a need for teacher awareness so that they actively can make use of the openings for deeper explorations of texts that occur in the contingency of teacher-student discussions to model critical reading of texts.

The theoretical and methodological diversity of the articles allows this special issue as a whole to provide a complex, multi-facetted understanding of the dynamic interplay between texts and classroom interaction in relation to literacy development in the collective setting of the classroom, while also taking into consideration aspects 
such as social interaction, materiality, corporality, ideology as well as subject matter. Below you will find a commentary by Kirsti Klette and Astrid Roe on the overall contribution that this collection of articles makes to the field of literacy research and to the understanding of contemporary literacy development in classrooms.

\title{
Carina Hermansson Umeå University
}

\author{
Eva Hultin \\ Högskolan Dalarna
}

\author{
Marie Tanner \\ Karlstad University
}

\section{References}

Ball, S.J., Maguire, M. \& Braun, A. (2012). How Schools do Policy: Policy Enactments in Secondary Schools. London: Routledge.

Barton, D. (1994). Literacy: an introduction to the ecology of written language. Oxford: Blackwell.

Breakspear, S. (2012). The Policy Impact of Pisa - An exploration of the normative effects of international benchmarking in school system performance. OECD Education Working papers, No 71, OECD Publishing.

Carlgren, I., Klette, K., Mýrdal, S., Schnack, K. \& Simola, H. (2006). Changes in Nordic teaching practices: From individualized teaching to the teaching of individuals. Scandinavian fournal of Educational Research, 50(3), 301-326. DOI: http://dx.doi.org/10.1080/00313830600743357

Dyson, A. H. (1997). Writing Superheroes: Contemporary Childhood, Popular Culture, and Classroom Literacy. New York: Teachers College Press.

Englund, T. (1993). Utbildning som "public good" eller "private good"? [Education as public good or private good.]. Uppsala: Pedagogiska institutionen, Uppsala universitet.

Grek, S. (2009). Governing by numbers: The Pisa 'effect' in Europe. Fournal of Education Policy, 24(1), 23 -37.

Hamilton, M. (2012). The effects of the literacy policy environment on local sites of learning. Language and Education, 26 (2), 162-182. DOI: http://dx.doi.org/10.1080/09500782.2011.642882

Heath, S. B. (1983). Ways with words: Language, life, and work in communities and classrooms. Cambridge: Cambridge University Press.

Hursh, D. (2007). Assessing No Child Left Behind and the Rise of Neoliberal Education Policies. American Educational Research fournal, 44(3), 493-518.

Lauder, H., Brown, P., Dillabough, J. \& Halsey, A. H. (Red.). (2006). Education, globalization and social change. Oxford: Oxford University Press.

Lingard, B., \& Rawolle, S. (2011). New scalar politics: implications for education policy. Comparative Education, 47(4), 489-502.

Luke, A. (2012). After the testing. Talking and reading and writing the world. Fournal of Adolescent $\mathcal{E}$ Adult Literacy, 56(1), 8-13.

OECD (2005). The definition and selection of key competences. Executive summary. Retrieved from https:// www.oecd.org/pisa/35070367.pdf

Street, B. (Ed.). (2005). Literacies across educational contexts: mediating learning and teaching. Philadelphia: Caslon

Tanner, M. (2014). Lärarens väg genom klassrummet. Lärande och skriftspråkande $i$ bänkinteraktioner på mellanstadiet. [Classroom trajectories of teaching, learning and literacy. Teacher-student desk interaction in the middle years.]. Karlstad: Karlstads universitet.

Vinterek, M. (2006). Individualisering $i$ ett skolsammanhang. [Individualization in a school context.]. Stockholm: Myndigheten för skolutveckling. 